of Moriguchi's 'accomplishments' was particularly disappointing. But other newspapers, including the Nihon Keizai Shimbun, have now admitted to having run unverified stories about Moriguchi over the past decade. Given the esoteric nature of the studies involved, reporting on science can be intimidating. So here are some practical steps to help a journalist challenge a specialist.

One can start by looking at publications. All scientists publish their results. If they don't it is a red flag. The publications give a scientist's affiliations, so if there is any doubt, it is easy to verify whether a scientist actually works where they say they do (a quick e-mail to Harvard University could have saved the Yomiuri Shimbun a lot of embarrassment). Publications also list the names of collaborators (making it easy to confirm with them that the scientist has done the experiments claimed), the names of the funders (making it easy to check whether resources were available) and declarations of conflicts of interest (revealing potential biases).

Most importantly, a journalist should talk to other researchers those who do not collaborate with the scientist in question - about the study's significance and feasibility. Such researchers can usually be found by consulting references in the publication. If not - and an absence of proper references would be a warning sign - an Internet search will quickly bring up names. Although probably truer of North America and Europe than elsewhere, scientists are generally committed to keeping junk out of the literature. If it looks like junk, they'll tell you.

Of course, Moriguchi said that his latest results were not yet published. That should have triggered further questioning. Why would he present his results to the media first? Some scientists have a reason for doing so; Moriguchi did not. And it should have prompted a closer look at his work experience and past publications. Why do records of his career - which were available online - suggest that he had little or no experience in the field in which he was claiming to have made a revolutionary breakthrough? Why did he profess to work in a non-existent university Division of iPS Cell Research and Application?

And why was he taking an unconventional and unfamiliar

technology to the clinic? When he was questioned directly, as he was by Nature, things got worse. Why, for example, did he refuse to give the names of collaborators on the latest study? Poking the surface led to an outpouring of dubious statements.

People get away with fraud everywhere, but in Japan it seems that there are cultural factors that mean it goes unreported. Japanese scientists are less likely to be critical of their colleagues; there is less protection of whistleblowers who might not want to risk their careers; and journalists in Japan can be too polite, perhaps intimidated by the

"Why would Moriguchi present his results to the mediafirst?" illustrious image carried by sensei and afraid to ask awkward questions. Possibly because of a lack of confidence in their English or because of differences between time zones, they often do not contact scientists overseas.

The situation is exacerbated by a recent Japanese epidemic: iPS-cell mania. With the excitement over Yamanaka's pioneering results, media outlets are rushing to get new iPS-cell stories first, sometimes regardless of their quality. This tendency is fuelled by a paranoid attachment to iPS-cell technology. Many news stories describe an international race to translate iPS-cell research into medical advances, which Japan might lose. This fear seems to have inspired Moriguchi, who lamented in 2009 that Japan was in danger of falling behind in iPS-cell research (in a Correspondence in Nature: H. Moriguchi and C. Sato Nature 457, 257; 2009), and the Yomiuri reporters, who even envisaged a 'flexible' approval system in the United States that might allow Moriguchi to continue with his research.

This is all very silly. The beautiful thing about iPS-cell technology and a major reason it won the Nobel prize - is that it can be used easily by scientists everywhere. If Japan wants to show its pride in Yamanaka's accomplishment, it should celebrate all achievements around the world. And if journalists want to understand just how important it is, they should put a new development in an international perspective.

\title{
Fight the power
}

\section{Independence of academic institutions is crucial if nations are to rebuild.}

$\mathrm{I}$ $t$ is said that truth is the first casualty of war. But after wars have ended and nations are rebuilding, truth is a potent foe, too.

1 A free press and a strong academic establishment pose great threats to a despotic regime, and are often the first to feel pressure. In a News Feature on page 24, we document such tensions in Eritrea, where there are efforts to remove foreign influences from the nation's medical schools and to break up its academic institutions. Eritreans who have fled or been exiled lament the sorry state of these institutions, and fear that by severing ties to US universities, the government has squandered chances of extraordinary gains in public health. (Representatives of the Eritrean government did not respond to several requests for comments on these and other allegations.)

Many who helped to lead Eritrea to its independence in 1991 and establish the current regime were academics, students and physicians - the very type of people (and, in some cases, the actual people) that the country's leaders are now marginalizing. This irony should not be a surprise, given that thriving academic institutions in new regimes can serve as hotbeds of dissidence, unrest and further revolution.

For a country such as Eritrea to reach a stable equilibrium, this destructive cycle must be broken. And this is perhaps the best lesson that Eritrea can give to nations that must build new governments. It is expected that academics will be involved in the overthrow of unjust regimes, and that they will subsequently be called on to support burgeoning governments. But these people must strive to remain independent from the start. The desire to trust and indulge former comrades may be strong, yet academics must reject all interference and resist any attempt by government to grab control of institutions.

To stand up to power in this way is difficult, but there is much at stake. Independent institutions will produce and support wellinformed, independent citizens, who remain the most effective defence against corruption and the abuse of power.

ANNOUNCEMENT

\section{Nature metrics}

s of last week, Nature now provides a real-time online count
Citation data, news mentions, blog posts and details of sharing
through social networks, such as Facebook and Twitter, will
be available for every research article published since last year.
Nature Publishing Group (NPG) hopes that the information
will be of interest to readers, as well as feeding into the evolv-
ing debate about alternative ways to evaluate scientific output.
The 2014 Research Excellence Framework exercise to assess UK
research quality, for instance, will look at article citations and
consider other measures for tracking research impact.
The information is available for 20 NPG journals published
on nature.com, including the Nature research journals, Nature
Communications and Scientific Reports. 